\title{
Yüksek Lisans Öğrencilerinin Demokrasiye İlişkin Görüşleri
}

\section{Graduate Students' Perceptions of Democracy}

Şeyma SAHIN ${ }^{l}$

Burcu ÖKMEN ${ }^{2}$

Abdurrahman KILIÇ3

Alıntılama: Şahin, Ş., Ökmen, B. \& Kılıı̧, A. (2020). Yüksek lisans öğrencilerinin demokrasiye ilişkin görüşleri. Ulusal Eğitim Akademisi Dergisi (UEAD), 4(1), 1-28.

Geliş tarihi:

7 Aralık 2019

Kabul tarihi:

2 Mart 2020

(C) UEAD 2020

Tüm haklarl

saklıdır.

Received:

7 December 2019

Accepted:

2 March 2020

(C) UEAD 2020

All rights reserved.

Özet: $\mathrm{Bu}$ araştırma ile; bir devlet üniversitesinde eğitim bilimleri ana bilimdalında yüksek lisans eğitimi alan öğrencilerin demokrasiye ilişkin algılarının belirlenmesi amaçlanmıştır. Araştırma, nitel araştırma desenlerinden "olgu bilim" deseni kapsamında yürütülmüştür. Araştırmanın çalışma grubunu, 2017-2018 eğitim öğretim yılı bahar döneminde bir devlet üniversitesinin "Eğitim Programları ve Öğretim" ile "Eğitim Yönetimi" yüksek lisans programlarından seçmeli "Demokrasi ve İnsan Hakları" dersini alan 14 katılımeı oluşturmaktadır. Veriler, "cümle tamamlama tekniği" ve "görüşme" yöntemi ile toplanmıştır. 27 tamamlanmamış cümleden oluşan "cümle tamamlama formu" ile dört açık uçlu sorudan oluşan "görüşme formu" veri toplama aracı olarak kullanılmıştır. Verilerin çözümlenmesinde içerik analizi yöntemi kullanılmıştır. Araştırmada, tüm insanların temel haklara sahip olmaları gerektiği ve bazı insanların temel haklara sahip olmaması gerektiği şeklinde iki farklı sonuca ulaşılmıştır. Demokrasinin hem olumlu hem de olumsuz algılandığı görülmüştür. Okul öncesinden başlayarak eğitimin her kademesindeki öğrencilerin demokrasi algılarının geliştirilmesi yönünde önerilerde bulunulmuştur.

Anahtar kelimeler: Demokrasi, demokrasi algısı, demokrasi ve insan hakları dersi, insan hakları, yüksek lisans öğrencileri.

Abstract: The aim of this study is to determine the democracy perceptions of teachers who are graduate students in a public university. The research was conducted within the scope of the phenomenologic qualitative research designs. The study group consisted of 14 participants who took "Democracy and Human Rights" selective course in "Curriculum and Instruction" and "Education Management" master programs in a public university in the spring term of 20172018 academic year. Data was collected by "sentence completion technique" and "interview" method. The "sentence completion form" consisting of 27 incomplete sentences and the "interview form" consisting of four open-ended questions were used as data collection tools. In data analysis, the content analysis method was used. In the research, two different conclusions were reached that all people should have basic rights and some people should not have basic rights. It has been seen that democracy was perceived both positively and negatively. Suggestions were made to improve the perception of democracy of students at all levels of education

\footnotetext{
${ }^{1}$ Dr. Düzce Üniversitesi, seyymasahin@gmail.com, ORCID ID: 0000-0003-1727-4772

${ }^{2}$ (Sorumlu Yazar) Dr. Düzce Üniversitesi, burcuokmen91@hotmail.com, ORCID ID: 0000-0002-0296-0078

${ }^{3}$ Prof. Dr. Düzce Üniversitesi, akilic52@hotmail.com, ORCID ID: 0000-0002-2704-2951
} 
starting from preschool.

Keywords: Democracy, democracy and human rights course, graduate students, human rights, perception of democracy.

\section{Giriș}

Demokrasiye ilk olarak antik çağda Yunan sitelerinde rastlanır. Bu sitelerde vatandaşlar "agora" ya da "forum" denilen meydanlarda toplanarak ülke yönetimi ile ilgili önemli konularda karar verirlerdi. Yunanlılar, 2500 yıl önce Atina'da kurdukları şehir devletlerinin yönetim şeklini ifade etmek için "Demokrasi" ya da "demokratia" terimini kullanırlardı (Vander Hook, 2011). Demokrasi, her ne kadar batı kaynaklı bir kavram olarak düşünülse de, İslam dininin de özünde; özgürlük, inanç hürriyeti, kanun önünde eşitlik, adalet ve şura gibi demokrasinin temel unsurlarının mevcut olduğu görülmekte (Ateş, 2017; Yargıc1, 2007), bugünkü karş1lı̆̆ parlamento olan "şura" ya da "meşveret" kurumu halkın yönetime katılımını işaret etmektedir (Koyuncu, 2015). Demokrasi, eski Yunandan günümüze kadar toplumların farklılaşan siyasal ve yönetsel beklentilerine uygun çözümler üretmeyi başarmış olan bir potansiyele sahiptir ve her dönemin ihtiyacı doğrultusunda sunduğu çözüm modelleriyle, bir önceki modelin eksikliklerini tamamlayarak kendini yeniden kurgulamayı başarmıştır (Özdemir, 2013). Böylece demokrasi farklı toplumlarda yaşanan tecrübelerle insanlığın ortak malı olmuştur denilebilir.

Robert Dahl'ın tanımında demokrasi; "sıradan vatandaşların liderler üzerinde nispeten yüksek derecede denetim uygulaması" olarak tanımlanmıştır (Olatunji, 2013: 19). Günümüzde kelime anlamından hareketle en yaygın biçimi ile "halkın kendi kendini yönetmesi" olarak tanımlanan demokrasi, daha gelişmiş bir tabirle; "yöneticilerin adil, özgür ve düzenli seçimler yoluyla halk tarafından ve halkın içinden seçildiği yönetim biçimi” olarak ifade edilebilir (Aktaş, 2015: 90). Demokrasi, sadece hukuksal ve siyasal bir gerçeklik olmayıp aynı zamanda bir yaşam biçimi ve ortak deneyimlerin paylaşılmasıdır. İnsanların nasıl bir arada yaşamaları gerektiği ile ilgili bilişsel ve duyuşsal yaşama dayalı eylemsel bir kavramdır. İnsanların bütün farklılıkları ile birbirlerini kabullerini, karşılıklı saygı ve hoşgörü hissetmelerini kapsar ve önce birey, sonra da yurttaş olmayı amaçlar (Çal, 2010; Dewey, 2001; Duman, 2008). Dahl (2001) demokrasinin; zorbalığı önleme, temel haklar, özgürlük, kendi kaderini tayin etme, ahlaki özerklik, insani gelişim, temel kişisel çıkarların korunması, eşitlik, barış ve refah gibi arzulanan toplumsal sonuçları doğurduğunu belirtmektedir. 
Demokrasilerde bazı değerlere ve ilkelere vurgu yapılır. Rosenfeld (2014) anayasal demokrasinin üç temel ve olmazsa olmaz unsuru olarak; devlet gücünün sınırlanması, hukukun üstünlüğüne bağlılık ve temel hakların korunmasını belirlemiştir. Schmidh (2002) demokratik yönetim biçiminin unsurlarını; demokrasi, genel, özgür, eşit seçim hakkı, partiler arası rekabet, tüm yurttaşlar için sağlıklı bilgi edinme, düşünce, muhalefet ve koalisyon özgürlüğü, oy hakkı sayesinde yöneticilerin düzenli olarak seçimle gelme, seçimle gitme imkanına sahip olması olarak sıralamıştır. Novak (1994) ile Osler ve Starkey (1994) ise demokrasinin temel kavramlarını adalet, eşitlik ve özgürlük olarak ifade etmektedirler. Bu çalışmada, demokrasinin temel unsurları olarak belirlenen; hukukun üstünlüğü, kuvvetler ayrılığı, yargının bağımsızlığı, eşitlik ve adalet, çoğulculuk, seçim ve muhalefet kavramlarına aşağıda kısaca değinilmiştir.

Hukukun üstünlüğü ilkesi, önceden konulmuş, ilan edilmiş, genel, düzenli, kesin, herkes için uygulanabilir, açık ve anlaşılır hukuk kurallarının varlığını gerektirmektedir. Bu kurallar, hukuku doğrudan iktidarın ya da sosyal organizasyonların etkisinden kurtarır (Palombella \& Morlino, 2010). Hukukun üstünlüğü ilkesi, kuvvetler ayrılığı, yargının bağımsızlığı ve sorumsuzluğu, eşitlik ve adalet ilkeleri ile de çok yakından bağlantılıdır (Nicolescu-Waggonner, 2016). Kuvvetler ayrılığg doktrininin özü; hiç kimsenin aşırı güç sahibi olmaması ve kurumlar arasında bir kontrol ve dengeler sistemi kurulması için yasama, yürütme ve yargı kurumlarının devletin farklı organlarında bulundurularak iktidarın tek elde toplanmasını engellemek ve bu üç kurumun birbirlerini denetleyebilmesini sağlamaktır (Khare, 2017).

Demokrasilerde, tüm insanlar varoluş anlamlarını ortaya koyma ve kendilerini gerçekleştirme ihtiyacı duyarlar. $\mathrm{Bu}$ anlamda tüm insanlar varoluşsal olarak eşit haklara sahiptirler. İnsanlara sırf insan olmalarından dolayı değer verilir. Eğitim, kariyer vb olanaklara erişim tüm vatandaşlara açık olmalı, kişiler sosyal konumları, zenginlikleri, cinsiyetleri gibi özellikler yoluyla değil, başarı, beceri ve yeteneklerine göre bu olanaklara erişim şansına sahip olmalıdırlar (Turner, 1986). Nielsen'e (1979) göre toplumdaki adalet bir bütün olarak, her insana hak ettiğinden bağımsız olarak eşit saygı ile muamele edilmesi ve her insana hak ettiğinden bağımsız olarak kendine saygı gösterme hakkına sahip olması gerektiği şeklinde anlaşılmalıdır.

Genel olarak her vatandaşın iyi bir hayat sürmesi ve karşısına çıkan firsatları değerlendirebilmesi için gerekli olan toplumsal koşulları sağlamayı amaçlayan, ayrıca her 
vatandaşın kendi hayatındaki kararlar, değerler ve projeler üzerinde eleştirel düşünme kapasitesine sahip olduğu ilkesini kabul eden (Reidy, 2001) demokrasinin temel kavramlarından bir diğeri çoğulculuktur. Toplumsal açıdan çoğulcu toplumlar, toplumsal grupların amaçları ve menfaatleri doğrultusunda organize olmalarına, örgütlenmelerine ve birbirleriyle rekabet etmelerine izin verilen toplumlardır (Conn, 1973).

Demokrasilerde, tüm milletin vekili olarak görev yapacak temsilciler genel oy, eşit oy ve serbest oy esasına dayanan serbest seçimlerle belirlenir (Tunç, 2008). Her ne kadar seçimler demokrasinin temel araçlarından biri olsa da, seçim tek başına demokrasinin göstergesi sayılamaz. Seçimlerin demokratik meşruiyet kazanması için, farklı görüşleri temsil eden partilerin serbestçe örgütlenebilmeleri ve seçim kulvarında her türlü baskıdan uzak, özgürlükçü bir ortamda yarışabilmeleri gerekir (Aliefendioğlu, 2005). Bazıları muhalefetsiz demokrasiyi tercih etseler ve siyasi partilerden hizipçilik kaynağı ve istikrar için tehdit olarak bahsetseler ve bazı ülkeler muhalefet partileri olmadan demokratikleşmeye çalışsalar da bu gibi durumlarda oluşan yapı demokratik açıdan oldukça zayıf bir yönetim şekli olacaktır (Lai \& MelkonianHoover, 2005).

Bir ülkenin vatandaşlarının davranış ve tutumlarının demokratiklik düzeyi ile o ülkede demokrasinin varlığı ve uygulanma düzeyi arasında sıkı bir ilişki vardır. Demokrasi; demokratik değerlere sahip, demokratik yollarla düşünebilen, demokratik davranış biçimlerini benimsemiş bireylerin varlığını gerekli kılmaktadır. Demokrasinin önemini fark etmiş ve günlük hayatında uygulamaya başlamış bireylerin yer aldığı bir toplumda demokrasinin yerleşmesi, huzur ve mutluluğun sağlanması mümkün olabilecektir. $\mathrm{Bu}$ nedenle demokratik bir toplumun oluşturulması için demokrasinin temel öğelerini iyi anlamış bireylerin yetiştirilmesi gerekmektedir (Bal \& Yiğittir, 2013; Bülbül, 1989; Büyükkaragöz, 1989). Bu bağlamda bu araştırma ile, yükseklisans yapmakta olan öğrencilerin demokrasiye ilişkin algılarının belirlenmesi amaçlanmıştır.

$\mathrm{Bu}$ amaçla aşağıdaki sorulara cevap aranmıştır:

1. Katılımcıların temel haklara yönelik algıları nasıldır?

2. Katılımcıların demokrasiye yönelik algıları nasıldır? 
3. Katılımcıların demokrasinin unsurlarına yönelik algıları nasıldır?

4. Katılımcıların demokratik toplum özelliklerine yönelik algıları nasıldır?

\section{Yöntem}

\section{Araştırma Modeli}

Araştırma, nitel araştırma desenlerinden "olgu bilim” deseni kapsamında yürütülmüştür. Olgu bilim çalışmalarında araştırmacılar, katılımcıların belli konulardaki deneyimlerinin özünü ortaya çıkarmaya çalışırlar (Cresswell, 2014). Bu araştırma ile ortaya konulmaya çalışılan olgu; yüksek lisans öğrencilerinin demokrasi algılarıdır.

\section{Katılımellar}

Araştırmada çalışma grubu oluşturulurken amaçlı örnekleme yöntemi kullanılmıştır. Nitel araştırmalarda, istatistiki bir temsil amaçlanmadığından problem durumunu yansıtmaya en uygun küçük bir grup ile derinlemesine çalışma yapmayı kolaylaştıracak çalışma ortamlarının oluşturulması hedeflenmektedir (Ritchie, Lewis \& Elam, 2003). Bu araştırmada amaç; "Demokrasi ve İnsan Hakları" dersini alan öğrencilerin ders öncesi görüşlerini belirlemek olduğundan, derse kayıt yaptıran öğrenciler katılımcı olarak seçilmiştir.

Araştırmanın çalışma grubunu 2017-2018 eğitim öğretim yılı bahar döneminde bir devlet üniversitesinin Eğitim Programları ve Öğretim (EPÖ) ile Eğitim Yönetimi ve Denetimi (EYD) yüksek lisans programlarından seçmeli "Demokrasi ve İnsan Hakları" dersini alan öğrenciler oluşturmaktadır. Bu öğrencilerin 10'u EYD ve 7'si EPÖ bölümünde öğrencidir. Öğrencilerin 10'u erkek ve 7'si kadındır. Araştırmanın çalışma grubunu bu 17 yüksek lisans öğrencisinden araştırmaya katılmak isteyen 13 gönüllü öğrenci oluşturmaktadır.

\section{Verilerin Toplanması}

Araştırmada veri toplama yöntemi olarak projeksiyon tekniklerinden olan "cümle tamamlama tekniği”" ile "görüşme" yöntemi kullanılmıştır. 
Projeksiyon teknikleri ile katılımcıların geleneksel araştırma teknikleri kullanıldığında ifade etmeye çekinecekleri kişisel duyguları öğrenilmeye çalışılır (Catterall \& Ibbotson, 2000). Cümle tamamlama tekniğinde; katılımcılara eksik cümleler sunulur ve onlardan bu cümleleri tamamlamaları istenir. $\mathrm{Bu}$ çalışmada öncelikle ayrıntılı literatür taraması yapılarak 27 tamamlanmamış cümleden oluşan "cümle tamamlama formu" oluşturulmuştur. Formda yer alan örnek bir cümle şu şekildedir: "Demokrasilerde muhalefet ............................ Bu form seçmeli "Demokrasi ve İnsan Hakları" dersi alan öğrencilere dönem başında uygulanmış ve öğrencilerden yarım bırakılmış cümleleri tamamlamaları istenmiştir.

Görüşme tekniğinde amaç; insanların yaşadıkları tecrübeleri ve bu tecrübelerin anlamlarını ortaya çıkarmak, kişilerin hayat hikayeleri yoluyla araştırma sorusunu aydınlatacak verilere ulaşmaktır (Kvale, 2006). Bu araştırma kapsamında literatür taraması sonrasında araştırmacılar tarafından hazırlanan sekiz açık uçlu sorudan oluşan görüşme formu kullanılmıştır. Formda yer alan örnek soru şu şekildedir: "Demokrasinin olumlu-olumsuz özellikleri açısından neler düşünüyorsunuz?". Hazırlanan "cümle tamamlama formu” ve "görüşme formu” aynı katılımcılar tarafindan gönüllü olarak doldurulmuştur.

\section{Veri Analizi}

Araştırma sonucu elde edilen verilerin çözümlenmesinde içerik analizi yöntemi kullanılmıştır. İçerik analizi, birbirlerine benzeyen verileri belirli kavramlar ve kategoriler çerçevesinde bir araya getirerek okuyucunun anlayacağı bir biçime dönüştürüp yorumlanmasını sağlar (Fraenkel \& Wallen, 2000).

"Cümle tamamlama tekniğii" yolu ile toplanan veriler ile "görüşme formu" yolu ile toplanan veriler öncelikle iki araştırmacı tarafından ayrı ayrı kodlanmıştır. Daha sonra kodlanan verilere daha yakından bakılmış ve verilerin özelliklerine dayalı olarak kategori oluşturma işlemi gerçekleştirilmiştir. $\mathrm{Bu}$ süreçte, verileri kategorilere dağıtma, verileri üst kategorilerde birleştirme, alt kategoriler oluşturma işlemleri gerçekleştirilmiştir. Daha sonra geliştirilmiş olan kategoriler arasındaki ilişkiler ve farklılıklar incelenmiştir. Ortaya çıkan sonuçlar tablolaştırılmıştır. Doğrudan alıntılarda kullanılmak üzere görüşme formları; KG1, KG2, ... KG14 şeklinde, cümle tamamlama formları; $\mathrm{KC1}, \mathrm{KC} 2, \ldots \mathrm{KC} 14$ şeklinde kodlanmıştır. 


\section{Geçerlik ve Güvenirlik}

Nicel araştırmalarda "geçerlik" ve "güvenirlik" kavramları kullanılırken, nitel araştırmalarda bu kavramlar yerine "güvenduyulabilirlik" kavramı ön plana çıkmaktadır. Güvenduyulabilirlik konusunda aşağıdaki kavramlar temel kriterler olarak kabul edilmektedir (Golafshani, 2003; Lincoln ve Guba, 1985):

$\checkmark$ İnandırıcılık: Araştırmacı ile katılımcılar arasında uzun süreli etkileşim sağlamak amacıyla veri toplama işlemi araştırmacılar tarafından öğrencilerin sınıflarında gerçekleştirilmiştir. Derin odaklı bilgi için veriler araştırmacılar tarafından tekrar tekrar okunmuş, kategoriler oluşturulmuş ve kategoriler arasındaki ilişkiler ve farklılıklar tekrar tekrar incelenmiştir. Bulguların inandırıcılığını sağlamak için iki farklı veri toplama tekniği kullanılmış ve çeşitleme yapılımıştır. Araştırmanın analiz sürecinde iki araştırmacı tarafından yürütülmüş, yani analizci çeşitlemesi yapılmıştır.

$\checkmark$ Uygulanabilirlik-Aktarılabilirlik: Verilerinin aktarılabilirliğini sağlamak amacıyla, araştırma süreci ayrıntılı olarak betimlenmiş ve raporlaştırılmıştır.

Tutarlılık-Güvenilebilirlik: $\mathrm{Bu}$ araştırmada analiz edilen veriler için akran incelemesi yapılmıştır. Akran incelemesi araştırmacının çalışması hakkında dürüst olmasına ve akranlarının verilerin analizine katkıda bulunmasına yardımcı olur (Anney, 2014). Araştırma verileri ve araştırma sonuçlarının birbirleriyle ilişkilendirilmesinde uzman görüşü alınmıştır.

$\checkmark$ Nesnellik-Onaylanabilirlik: Verilerin yorumlanmasında nesnel davranılmış ve araştırmacının eğilimleri araştırmaya yansıtılmamıştır. Araştırmanın başlangıcından raporlanmasına kadar olan süreç şeffaf bir şekilde tanımlanmışırı. Veri toplama formlarından yapılan doğrudan alıntılarla da nesnellik-onaylanabilirlik desteklenmiştir. Araştırmanın ham verileri gerektiğinde incelenmek amacıyla saklanmıştır.

\section{Bulgular}


Analizler sonucu araştırma bulguların; Temel Haklara Yönelik Algılar, Demokrasiye Yönelik Algılar, Demokrasinin Unsurlarına Yönelik Algılar ve Demokratik Toplum Özelliklerine Yönelik Algılar olmak üzere dört ana başlık altında toplandığı görülmüştür.

\section{Temel Haklara Yönelik Algılar}

Temel haklara kimlerin sahip olması gerektiği ve temel haklara neden sahip olunması gerektiğine dair katılımcı görüşleri Tablo 1'de sunulmuştur:

Tablo 1. Temel Haklara Sahip Olma

\begin{tabular}{ll}
\hline \multirow{2}{*}{ Temel Haklara } & Tüm insanlar \\
Kimler Sahip Olmalı & Bazı insanlar \\
& Temel haklara layık olanlar \\
& Başkasının haklarını ihlal etmeyenler \\
\hline & Tüm insanlar eşittir, temel haklara eşit derecede sahiptir \\
Temel Haklar Neden & Temel haklar nitelikli yaşam için gereklidir \\
Gereklidir & Temel haklar doğuştan kazanılır \\
& Temel haklar insan olmanın gereğidir \\
& Her birey toplumun parçasıdır \\
\hline
\end{tabular}

Tablo 1 incelendiğinde, katılımcıların tüm insanların temel haklara sahip olmaları gerektiğini düşündükleri gibi, tüm insanların temel haklara sahip olmaya layık olmadıklarını düşündükleri de görülmektedir. İnsanların temel haklara neden sahip olmaları gerektiği konusunda ise tüm insanların eşit olduğu ve temel haklara eşit derecede sahip olmaları gerektiği fikri öne çıkmaktadır. İnsanın kainattaki en değerli varlık olduğu ve temel hakların insan olmanın bir gereği olarak doğuştan kazanıldığı belirtilmektedir.

Temel haklara sahip olma ile ilgili katılımcı görüşlerinden bazı alıntılar aşağıda verilmiştir:

KG2: “Tüm insanlar bu haklara sahiptir. Yaratıllştan tüm insanlar eşittir ve insanca yaşamak için bu haklara sahip olmalıdır.”

KG3: "Dünya üzerindeki her birey buna layık olmalıdır. Çünkü her birey dünya toplumunun öz bir parçasıdır."

KG6: "Belli çerçevede herkes haklarını kullanmaya layıktır. Ancak cinsel istismar, kadına şiddet, insanların ölümüne sebep olma gibi davranışları yapanların bunlara layık olmadı̆̆ını düşünüyorum."

\section{Demokrasiye Yönelik Algılar}


Katılımcıların demokrasiye yönelik olumlu ve olumsuz görüşleri Tablo 2'de sunulmuştur:

Tablo 2. Demokrasiye Iliş̧kin Görüşler

\begin{tabular}{ll}
\hline & Yönetimde söz sahibi olma \\
& Düşünceleri ifade edebilme \\
& Adaleti/eşitliği sağlama \\
Olumlu Görüşler & Hak ve özgürlüklerin korunması \\
& Değişime katkı sağlama \\
& Her bireye önem verme \\
& Bireyin geleceğini kendisinin belirlemesi \\
\hline & Çoğunluğun etkisinin artması \\
& Azınlığın memnuniyetsizliği \\
& Karar almanın uzun zaman gerektirmesi \\
& Halkın kolaylikla kandırılabilmesi \\
& Herkesin (eğitimsiz bireylerin) oyunun eşit olması \\
& Söz sahibi olanların ayricalılılıvinranması \\
& Yönetici seçiminde liyakat sorunu \\
& İstikrarın engellenmesi \\
& Olağanüstü şartlarda uygulanmasının zor olması \\
\hline
\end{tabular}

Tablo 2 incelendiğinde demokrasi ile ilgili olarak olumlu ve olumsuz görüşlerin olduğu görülmektedir. Katılımcıların demokrasi ilgili; yönetimde söz sahibi olma, düşünceleri ifade edebilme, adaleti ve eşitliği sağlama, hak ve özgürlüklerin korunması, değişime katkı sağlama, her bireye önem verme ve bireyin geleceğini kendisinin belirlemesi gibi olumlu görüşleri mevcuttur.

$\mathrm{Bu}$ görüşlerin yanısıra katılımcıların demokrasi ile ilgili olumsuz görüşleri de vardır. Bunlar; çoğunluğun azınlık üzerinde baskı kurması, eğitimsiz bireylerin karar verici olması, herkesin oyunun eşit olması, karar almanın uzun zaman gerektirmesi, halkın kolaylıkla kandırılabilmesi, istikrarın engellenmesi ve kargaşaya sebep olması gibi görüşlerdir.

Demokrasinin olumlu ve olumsuz yönlerine ilişkin katılımcı görüşlerinden bazı alıntılar aşağıda verilmiştir:

KG7: "Demokrasi; kararların alınmasın yavaşlatır, iyi kontrol edilmezse kargaşaya sürükler. Istikrarı engelleyebilir."

KG8: "Dağdaki çoban ile okuyan eliştiren insanların oyunun eşit olmaması gerektiğini düşünüyorum." 
Şahin, Ökmen \& Kılıç (2020)

KG10: "Toplumu oluşturan bireylerin yönetimde fikir sahibi olması, bireyin geleceğini kendi özgür iradesi ile kendi belirleyebilmesi."

\section{Demokrasinin Unsurlarına Yönelik Algılar}

Bu başlık altında; "Hukuk ve Adalet”, "Hürriyet ve Merhamet”, "Muhalefet ve Seçim” ile "Çoğulculuk" olmak üzere dört tema yer almaktadır. Bu temalar aşağıda alt başlıklar halinde açıklanmıştır.

\section{Hukuk ve Adalet}

Hukuk ve adalete ilişkin katılımcı görüşleri Tablo 3'te sunulmuştur:

Tablo 3. Hukuk ve Adalet

\begin{tabular}{|c|c|c|}
\hline \multirow{2}{*}{ Hukuk } & Belirlenmesi & $\begin{array}{l}\text { Toplum tarafindan belirlenmeli } \\
\text { Toplumun ihtiyaçlarına göre belirlenmeli } \\
\text { Temel hak ve özgürlükler temelinde hazırlanmalı }\end{array}$ \\
\hline & Korunması & $\begin{array}{l}\text { Uyum gösterilmeli, saygı duyulmalı } \\
\text { Devlet tarafindan güvence altına alınmalı } \\
\text { Uymayanlar cezalandırılmalı }\end{array}$ \\
\hline \multirow[t]{2}{*}{ Adalet } & Tesisi & $\begin{array}{l}\text { Yasa ile } \\
\text { Demokrasi ve unsurları ile } \\
\text { Devlet kontrolü ile } \\
\text { Eğitim ile } \\
\text { Mümkün değil }\end{array}$ \\
\hline & İşlevi & $\begin{array}{l}\text { Emniyet, güven, asayiş } \\
\text { Özgürlük, bağımsılık } \\
\text { Devletin bekası } \\
\text { Haklı ile haksızın ortaya çıkması } \\
\end{array}$ \\
\hline
\end{tabular}

Tablo 3 incelendiğinde hukukla ilgili olarak "belirlenmesi" ve "korunması" olmak üzere iki alt temanın ortaya çıktığı görülmektedir. Hukukun temel hak ve özgürlükler temelinde toplum ihtiyaçlarına göre belirlemesi gerektiği düşünülmektedir. Korunması için ise kişilerin hukuka sayg1 göstermesinin, hukukun devlet tarafından garanti altına alınarak uymayanların cezalandırılmasının gerekli olduğu belirtilmiştir.

Adalet ile ilgili olarak "tesisi" ve "işlevi” olmak üzere iki alt tema oluşmuştur. Katılımcılar; yasa ve hukuk yolu ile; eşitlik, düşünce hürriyeti, temel hak ve özgürlükler gibi demokrasinin unsurları yolu ile; devlet kontrolü ile ve eğitim yolu ile adaletin tesis edilebileceğini düşünmektedirler. Katılımcılar adaletin işlevi olarak da emniyet, güven, asayiş, özgürlük, bağımsızlık, devletin bekası ve haklı ile haksızın ortaya çıkmasını saymışlardır. 
Hukuk ve adalete ilişkin katılımcı görüşlerinden bazı alıntılar aşağıda verilmiştir:

KC1: "Adaletin tesis edilmesi için güçlü bir devlet şarttır."

KC5: "Hukuk kuralları toplumun yaşaylşı ve dönemin özelliklerine göre belirlenmelidir."

KC7: "Toplumun yasalart toplumun gerekliliklerine göre belirlenmelidir."

KC8: "Toplumun yasaları toplumun gerekliliklerine göre belirlenmelidir."

\section{Hürriyet ve Merhamet}

Hürriyet ve merhamete ilişkin katılımcı görüşleri Tablo 4'te sunulmuştur:

Tablo 4. Hürriyet ve Merhamet

\begin{tabular}{lll}
\hline & & Elzem \\
& Zor kazanılan, kolay kaybedilen & Özgürlük \\
& Tanım & On şart \\
Hürriyet & & En temel hak \\
& & Ülkemizde gazete adı \\
\cline { 2 - 3 } & & Kendisine zarar vermemeli \\
& Kullanım & Başkasına zarar vermemeli \\
& & Sonsuz değildir \\
& & Her insan kullanabilmeli \\
\hline & İktidar sahipleri/yöneticiler \\
& Güçlüler, zenginler, büyükler \\
& Merhamet & Herkes \\
& Edecekler & İnsan olanlar \\
& Bir gün merhamete ihtiyaç duyacak olanlar \\
& Hiç kimse (hukuk devletinde merhamete ihtiyaç yoktur) \\
\cline { 2 - 3 } Merhamet & Herkes \\
& Yönetenler \\
& Hürmet & Küçükler, fakirler \\
& Edecekler & Hürmet bekleyenler \\
& Güçlüler \\
\hline
\end{tabular}

Tablo 4 incelendiğinde hürriyetle ilgili olarak "tanımı" ve "kullanımı" olmak üzere iki alt temanın ortaya çıtığı görülmektedir. Katılımcıların hürriyeti tanımlamak için; elzem, özgürlük, temel hak ve özgürlük, ön şart gibi kavramları kullandıkları görülmektedir. Ayrıca hürriyetin bulunmadığını belirtmek için kullanıldığı düşünülen "ülkemizde gazete adı" ifadesi de yer almaktadır. Kullanımı ile ilgili olarak ise; her insanın kendisine ve başkalarına zarar vermeden hürriyete sahip olması gerektiği vurgulanmıştır.

Merhamet ile ilgili; kimlerin merhamet etmesi gerektiği ve kimlerin hürmet etmesi gerektiği ile ilgili olarak iki alt tema oluşmuştur. Bazı katılımcılar herkesin, bazıları iktidar 
sahipleri ve yöneticilerin, bazıları güçlüler, zenginler ve büyüklerin merhamet etmesi gerektiğini belirtmişlerdir. Kimlerin hürmet etmesi gerektiği ile ilgili olarak da bazıları herkesin, bazıları yöneticilerin, bazıları güçlülerin, bazıları ise küçükler ve fakirlerin hürmet etmesi gerektiğini belirtmişlerdir.

Hürriyet ve merhamete ilişkin katılımcı görüşlerinden bazı alıntılar aşağıda verilmiştir:

$\mathrm{KC} 1$ : "Hürriyet insanların başkalarının haklarına girdiği yerde biter."

KC3: "Hürriyet, sonsuz özgürlük demek değildir."

KC5: "Merhamet göstermesi gerekenler herkestir. Herkes birbirinin varliğına saygı göstermelidir."

KC8: "Merhamet göstermesi gerekenler insan olduğunun bilincinde olanlardır."

\section{Muhalefet ve Seçim}

Muhalefet ve seçime ilişkin katılımcı görüşleri Tablo 5'te sunulmuştur:

Tablo 5. Muhalefet ve Seçim

\begin{tabular}{|c|c|c|}
\hline \multirow[b]{2}{*}{ Muhalefet } & Konum & $\begin{array}{l}\text { Söz sahibi olmalı } \\
\text { Mutlaka bulunmalı } \\
\text { İktidarla aynı güce sahip olmalı }\end{array}$ \\
\hline & Sorumluluklar & $\begin{array}{l}\text { Doğruya doğru, yanlışa yanlış demeli } \\
\text { Farklı düşünceleri savunmalı } \\
\text { Toplumun her kesimini temsil etmeli } \\
\text { Yapıcı ve işbirlikçi olmalı } \\
\text { Kendini bu ülkenin parçası olarak görmeli }\end{array}$ \\
\hline \multirow{3}{*}{ Seçim } & Olumlu Özellikler & $\begin{array}{l}\text { Demokrasinin olmazsa olmaz unsurudur } \\
\text { İnsanlar özgürce kendilerini ifade ederler } \\
\text { Temel hak ve özgürlükleri destekler }\end{array}$ \\
\hline & $\begin{array}{l}\text { Olumsuz } \\
\text { Özellikler }\end{array}$ & $\begin{array}{l}\text { Her zaman doğru sonucu vermez } \\
\text { Her zaman adil değildir } \\
\text { Güven veren bir uygulama değildir }\end{array}$ \\
\hline & Nasıl Olmalıdır & $\begin{array}{l}\text { Hakkaniyetli, tarafsız olmalıdır } \\
\text { Usulüne uygun yapılmalıdır } \\
\text { Özgür iradeyle olmalıdır } \\
\text { Herkesin katılımı sağlanmalıdır }\end{array}$ \\
\hline
\end{tabular}

Tablo 5 incelendiğinde muhalefet ile ilgili olarak "konum" ve "sorumluluklar" olmak üzere iki alt temanın ortaya çıktığı görülmektedir. Konum ile ilgili olarak; muhalefetin mutlaka bulunması, söz sahibi olması ve hatta iktidarla aynı güce sahip olması gerektiği belirtilmiştir. 
Sorumlulukları arasında ise; doğruya doğru, yanlışa yanlış demek, farklı düşünceleri savunmak, tamamlayıcı olmak, yapıcı ve işbirlikçi olmak gibi görevler sayılmışıtır.

Seçim alt temasında ise; seçimin katılımcılara göre olumlu ve olumsuz özellikleri ile nasıl olması gerektiği ile ilgili düşünceler yer almaktadır. Katılımcılar seçimin olumlu özellikleri ile ilgili olarak; insanların özgürce kendilerini ifade edebilmelerini, demokrasinin fiilen bir uygulaması olduğunu ifade ederlerken, seçimin olumsuz özellikleri ile ilgili olarak da; her zaman doğru sonucu vermediğini, her zaman adil olmadığını ve güven veren bir uygulama olmadığını belirtmişlerdir. Katılımcıların seçimin nasıl olması gerektiği ile ilgili olarak; hakkaniyetli, tarafsız, usulüne uygun, özgür iradeyle ve herkesin katılımı sağlanarak yapılmasını saydıkları görülmektedir.

Muhalefet ve seçime ilişkin katılımcı görüşlerinden bazı alıntılar aşağıda verilmiştir:

$\mathrm{KC1}$ : "Muhalefet her zaman söz sahibi olmall ve görüşleri dikkate alınmalıdır."

KC3: "Muhalefet gördüğü doğruyu desteklemeli ve yanlışı eleştirmelidir."

KC9: "Seçimler her zaman adil olmaz."

KC11: "Seçimler ve seçim kampanyaları tarafsız yapılmalıdır."

\section{Çoğulculuk}

Çoğulculuğun özelliklerine ilişkin katılımcı görüşleri Tablo 6'da sunulmuştur:

Tablo 6. Çoğulculuk

\begin{tabular}{|c|c|c|}
\hline \multirow[t]{2}{*}{ Farklılıklar } & Olumlu & $\begin{array}{l}\text { Tek tip insan oluşumunu engeller } \\
\text { Temel hak ve özgürlükleri güçlendirir } \\
\text { Zenginlik, renkliliktir } \\
\text { Kutuplaşmayı gerektirmez } \\
\text { Saygı ve hoşgörü gerektirir } \\
\text { Toplumu geliştirir, güçlendirir, dinamik tutar }\end{array}$ \\
\hline & Olumsuz & $\begin{array}{l}\text { Demokrasiyi zayıflatır } \\
\text { Ortak noktada birleşmeyi engeller }\end{array}$ \\
\hline \multirow[t]{2}{*}{ Öteki } & Olumlu & $\begin{array}{l}\text { Farklılık } \\
\text { Güzellik } \\
\text { Sorun değil } \\
\text { Fikirlerini özgürce ifade etmek } \\
\text { Aynıs1 olmaktan iyi olan } \\
\text { Ötekileştirilmemesi gereken } \\
\end{array}$ \\
\hline & Olumsuz & $\begin{array}{l}\text { Topluma zararlı olan } \\
\text { Bazen kötü olan } \\
\text { Olumsuz etkileri olan }\end{array}$ \\
\hline Azınlıklar & Olumlu & Hak ve özgürlüklerini kullanabilmeli \\
\hline
\end{tabular}




\section{Değer verilmeli \\ Kendi kimliklerini yaşamalı \\ Bask1 yapılmamalı, ezilmemeli \\ Parlamentoda temsil edilmeli \\ Yadirganmamalı}

Tablo 6 incelendiğinde çoğulculukla ilgili olarak "farklılıklar”, “öteki”" ve "azınlıklar” olmak üzere üç alt temanın ortaya çıktığı görülmektedir. Katılımcıların farklılıklarla ilgili olumlu ve olumsuz gördükleri bazı özellikler belirlenmiştir. Olumlu olarak; farklılıkların olmasının doğal oluşu, tek tip insan oluşumunu engellemesi, zenginlik ve renk oluşu, toplumu geliştirmesi ve güçlendirirmesi gibi özellikler belirtilmiştir. Bu görüşlerin yanısıra katılımcıların farklılıklar ile ilgili olumsuz görüşleri de mevcuttur. Bunlar; farklılıkların demokrasiyi zayıflattı̆̆ı ve ortak noktada birleşmeyi engellediği görüşleridir.

“Öteki” ile ilgili olarak da katılımcıların olumlu ve olumsuz bazı görüşleri mevcuttur. Öteki ile ilgili olumlu olarak; farklılık, güzellik, aynısı olmaktan iyi olan gibi yorumlar yapılmıştır. Olumsuz olarak ise; topluma zararlı olan, bazen kötü olan ve olumsuz etkileri olan gibi bazı tanımlamalar kullanılmıştır.

Azınlıklarla ilgili olumsuz görüşler mevcut değildir. Olumlu olarak ise; hak ve özgürlüklerini kullanabilmeli, fikirlerine değer verilmeli, kendi kimliklerini yaşamalı, bask1 yapılmamalı, parlamentoda temsil edilmeli, çoğunluk kadar değerli olmalı gibi yorumlar yapılmıştır.

Çoğulculuğa ilişkin katılımcı görüşlerinden bazı alıntılar aşağıda verilmiştir:

KC1: "Farklı görüşlerin oluşu toplumu geliştirir ve güçlendirir."

KC2: "Farklılıkların ortadan kalkması tek tip insanların olduğu toplulukları oluşturur."

KC3: "Etnik ya da görüş olarak azınlıkta olanlara tüm haklarını kullanma imkanı taninmalıdır."

\section{Demokratik Toplum Özelliklerine Yönelik Algılar}

Bu başlık altında; "Devlet/Yönetici Özellikleri” ile "Vatandaş Özellikleri” olmak üzere iki tema yer almaktadır. Bu temalar aşağıda alt başlıklar halinde açıklanmıştır.

\section{Devlet/Yönetici Özellikleri}

Devlet/yönetici özelliklerine ilişkin katılımcı görüşleri Tablo 7'de sunulmuştur: 
Tablo 7. Devlet/Yönetici Özellikleri

\begin{tabular}{ll}
\hline \multirow{3}{*}{ Özgürlükler } & Hak ve özgürlükler kısıtlanmamalı, güvence altına alınmalı \\
& Hürriyet sağlanmalı \\
& Düşünce özgürlüğ̈̈ tesis edilmeli \\
\hline & Adalet ve eşitlik tesis edilmeli \\
Hak, Hukuk ve & Tarafsızlık ilkesi benimsenmeli \\
Adalet & Hukuka bağlı kalınmalı \\
& Haklı olanın yanında olunmalı \\
& Azınlıkların, zayıf olanların hakları korunmalı \\
\hline
\end{tabular}

Tablo 7. (devamı)

\begin{tabular}{ll}
\hline & Toplumun ihtiyaçları karşılanmalı, refahı sağlanmalı, çıkarları korunmalı \\
& Toplumun birliği sağlanmalı \\
Topluma Hizmet & Her bireyin değerli olduğu kabul edilmeli \\
& Sosyal devlet anlayışı benimsenmeli \\
& Güçsüz güçlendirilmeli \\
& Sanat, ilim ve bilimin gelişimi desteklenmeli \\
\hline & Halkın iradesi esas olmalı \\
& Halk temsil edilmeli \\
& Güç tek kişide toplanmamalı \\
& Güçler birliği olmalı \\
& Halkın tamamının desteği alınmalı \\
& Coğunluk ikna edilmeli \\
& İstidata ve kaliteye dayalı seçilmeli \\
\hline & Empati yeteneğine sahip olmalı \\
& Liderlik yapabilmeli \\
& İleri görüşlü olmalı \\
& Millete hizmetkar olmalı, ağası olmamalı ve Seçim \\
& Çkar gütmemeli \\
& Bulunduğu konumun hakkını vermeli \\
& Halka örnek olmalı \\
& Halkın önünde hesap verebilmeli \\
\hline
\end{tabular}

Tablo 7 incelendiğinde demokratik toplumda devlet ve yönetici özellikleri olarak; "özgürlükler", "hak, hukuk ve adalet", "topluma hizmet", "temsil ve seçim" ile "yönetici özellikleri” olmak üzere beş alt temanın ortaya çıktığı görülmektedir.

Özgürlük alt temasında devlet ve yöneticilerin özgürlükler konusunda nasıl davranması gerektiği ile ilgili görüşler bulunmaktadır. Bunlardan bazıları; hak ve özgürlüklerin kısıtlanmaması ve güvence altına alınması, hürriyetin ve düşünce özgürlügünün sağlanması, tüm düşüncelere saygı duyulmasıdır. Hak, hukuk ve adalet alt temasında; eşitlik ilkesinin korunması, adalet ve tarafsızlığın tesis edilmesi, hukuka bağlı kalınması gibi devlet ve yöneticilerin uygulaması gerektiği düşünülen bazı ilkeler bulunmaktadır. Topluma hizmet alt temasında; sosyal devlet anlayışının benimsenerek toplumun ihtiyaçlarının karşılanması, refahının sağlanması ve çıkarlarının korunması, toplum birliğinin sağlanması, toplumun ileri taşınması gibi 
toplumu ilgilendiren bazı görüşler mevcuttur. Temsil ve seçim alt temasında; katılımcıların devlet ve yöneticilerin temsili ve seçimi ile ilgili bazı görüşleri bulunmaktadır. Bunlardan bazıları; halkın iradesinin esas olması ve yöneticilerin halk tarafından istidata dayalı olarak seçilmesidir. Katılımcılar demokratik toplumda bulunması gereken yönetici özellikleri ile ilgili olarak; empati yeteneğine sahip olma, liderlik yapabilme, ileri görüşlü olma, millete hizmetkar olma gibi özellikleri saymışlardır.

Devlet/yönetici özelliklerine ilişkin katılımcı görüşlerinden bazı alıntılar aşağıda verilmiştir:

KC9: "Yöneticiler halktan geldiğini unutmamalıdır."

KC10: "Yöneticilerin diğer insanlara örnek olmalarl gerekir."

KC12: "Liderler geleceği gören kişiler olmalı ve çıkar gütmeden idare etmelidirler."

\section{Vatandaş Özellikleri}

Devlet/yönetici özelliklerine ilişkin katılımcı görüşleri Tablo 8'de sunulmuştur:

Tablo 8. Vatandaş Özellikleri

\begin{tabular}{|c|c|c|}
\hline \multirow{3}{*}{$\begin{array}{l}\text { Toplumsal } \\
\text { Açıdan }\end{array}$} & Topluma Hizmet & $\begin{array}{l}\text { Toplumun gelişimine katkı sağlamalı } \\
\text { Başkalarına yol göstermeli } \\
\text { Bilgilerini başkaları ile paylaşmalı }\end{array}$ \\
\hline & İnsan Haklarına Saygı & $\begin{array}{l}\text { Başkalarının hak ve özgürlüklerini kısıtlamamalı } \\
\text { Başkaları üzerinde baskı kurmamalı } \\
\text { Başkalarına saygı duymalı, önemsemeli } \\
\text { Başkalarına karşı hoşgörülü olmalı }\end{array}$ \\
\hline & Barış & $\begin{array}{l}\text { Toplumsal barış için çalışmalı } \\
\text { Kutuplaşmak yerine birleşmeli }\end{array}$ \\
\hline \multirow{3}{*}{ Bireysel Açıdan } & Hak ve Hukuk & $\begin{array}{l}\text { Temel hak ve özgürlüklerine sahip çıkmalı } \\
\text { Adalete riayet etmeli } \\
\text { Haklarını bilmeli ve doğru kullanmalı } \\
\text { Hukuk düzeninden çıkmamalı }\end{array}$ \\
\hline & Ahlaki Özellikler & $\begin{array}{l}\text { Akıl ve vicdan sahibi olmalı } \\
\text { Doğru yol üzere olmalı } \\
\text { Özverili ve ahlaklı olmalı }\end{array}$ \\
\hline & Eğitim & $\begin{array}{l}\text { Nitelikli yetişmeli } \\
\text { Potansiyelini keşfetmeli }\end{array}$ \\
\hline
\end{tabular}

Tablo 8'de demokratik toplumdaki vatandaş özellikleri bireysel ve toplumsal açıdan gruplandırılmıştır. Toplumsal açıdan vatandaşın görevleri arasında; toplumun gelişimine katkı sağlama, başkalarını önemseme, onlara yol gösterme ve onlarla bilgilerini paylaşma gibi topluma hizmetle ilgili sorumluluklar; başkalarının hak ve özgürlüklerini kısıtlamama, onlar üzerinde 
baskı kurmama, onlara saygı duyma gibi insan hakları ile ilgili sorumluluklar; toplumsal barış için çalışma ve kutuplaşmak yerine birleşme gibi barışla ilgili sorumluluklar sayılmıştır.

Bireysel açıdan vatandaşın görevleri arasında ise; temel hak ve özgürlüklerine sahip çıkma, adalete riayet etme, haklarını bilme ve kullanma gibi hak ve hukukla ilgili sorumluluklar; akıl ve vicdan sahibi olma, özverili olma ve ahlaklı olma gibi ahlaki sorumluluklar, nitelikli yetişme ve potansiyelini keşfetme gibi eğitim ile ilgili sorumluluklar sayılmıştır.

Vatandaş özelliklerine ilişkin katılımcı görüşlerinden bazı alıntılar aşağıda verilmiştir:

KC1: "Devletin bekası için bireyler temel hak ve özgürlüklerine sahip çıkmalıdır."

$\mathrm{KC} 2$ : "Toplumun geleceği için bireyler yararlı olacak şekilde topluma katılmalıdır."

KC5: "Bireylerin artık kutuplaşmak yerine birleşmesi lazım."

\section{Sonuç, Tartışma ve Öneriler}

Bu bölüm; Temel Haklara Yönelik Algılar, Demokrasiye Yönelik Algılar, Demokrasinin Unsurlarına Yönelik Algılar ve Demokratik Toplum Özelliklerine Yönelik Algılar olmak üzere dört başlık altında sunulmuştur:

\section{Temel Haklara Yönelik Algılar}

Araştırmada, tüm insanların temel haklara sahip olmalarl gerektiği ve bazı insanların temel haklara sahip olmaması gerektiği şeklinde iki farkl sonuca ulaşılmuştır. Insanların temel haklara neden sahip olmalar gerektiği konusunda; tüm insanların eşit olduğu ve temel haklara eşit derecede sahip olmalart gerektiği, insanın kainattaki en değerli varllk olduğu ve temel hakların insan olmanın bir gereği olarak doğuştan kazanıldığı görüşleri ortaya çıkmıştır.Tüm insanların temel haklara sahip olmaya layı olmadıkları düşüncesi demokrasi açısından olumlu bir algı değildir. Çünkü temel haklar insan olmanin bir gereği olarak doğuştan kazanılırlar. Bu açıdan bakıldı̆̆ııda temel haklara sahip olma noktasında yanlış algının var olduğu görülmektedir.

Gülmez (2009) doğuştan edinilen ya da sonradan kazanılan/kazanılmayan özelliklere bakılmaksızın insan haklarından eşitlik temelinde yararlanmada ayrımcılık gözetilmemesinin, insan haklarının özünü oluşturan temel bir ilke olduğunu belirtmektedir. Kuçuradi (2009) kişinin kim olduğu önemli olmadan, insan olması dolayısıyla haklarının korunması gerektiğini 
belirtirken, Tosun (2015) da etik bir bütünlüğe sahip olan bir kişinin, karşısındaki kişiyi değerli görüp, kendisinin sahip olduğu ya da sahip olmayı umduğu haklara onun da sahip olmasını istemesi gerektiğini belirtmektedir.

\section{Demokrasiye Yönelik Algılar}

Araştırma sonuçları demokrasinin; yönetimde söz sahibi olma, düşünceleri ifade edebilme, adaleti ve eşitliği sağlama, hak ve özgürlüklerin korunması, değişsime katkı sağlama, her bireye önem verme ve bireyin geleceğini kendisinin belirlemesi gibi açılardan olumlu olarak algılandığını göstermektedir. Çünkü demokrasi kavramı adalet, eşitlik, hak ve özgürlüklerin korunması kavramlarından ayrı düşünülmez.

Özdaş, Ekinci ve Bindak’ın (2014) öğretmenlerin demokrasi algılarını belirlemek için yaptıkları çalışmada, öğretmenlerin genel olarak demokratik tutumlarının yüksek olduğu sonucuna ulaşılmıştır. Yüce ve Demir'in (2011) polis adaylarının demokrasi algılarını belirlemeye yönelik olarak yaptıkları çalışmada polis adaylarının \%81.46'sının olumlu demokrasi algısına sahip oldukları bulunmuştur. Olumlu demokrasi algısına sahip polis adaylarının, demokrasiyi toplum ve birey için vazgeçilmez bir unsur olarak algıladıkları görülmüştür. Sarı ve Sadık’ın (2011) öğretmen adayları ile yaptıkları çalışmada da öğretmen adaylarının demokrasiyi toplumsal yaşamın temeli ve huzurun devamlılığı için olmazsa olmaz olarak ifade ettikleri, demokrasiye gereken önemi verdikleri görülmüştür.

Araştırma sonuçları demokrasinin; çoğunluğun azınlık üzerinde baskı kurması, eğitimsiz bireylerin karar verici olması, karar almanın uzun zaman gerektirmesi, herkesin oyunun eşit olması, istikrarın engellenmesi, kargaşaya sebep olması, halkın kolaylıkla kandırılabilmesi, azınlığın memnuniyetsizliği gibi açılardan da olumsuz olarak algılandığını göstermektedir.Tüm bu olumsuz algılar, demokrasi hakkındaki eksik ya da yanlış bilgilerin ya da uygulamada görülen eksikliklerin bir sonucudur. Demokrasi gücün bireylerde toplanmasına engel olan bir sistemdir. Farklı dünya görüşlerine sahip olan insanların, diğerinin varlığını ortadan kaldırmadan, birarada yaşamaları ilkesi üzerine kuruludur ve doğru uygulandığında kargaşa ve istikrarsızlı̆̆a değil huzur ve istikrara ulaştırır.

Yüce ve Demir'in (2011) polis adayları ile yaptıkları çalışmada olumsuz demokrasi algısına sahip polis adaylarının demokrasinin bireyleri güç sahibi yaptığı ve demokrasinin 
erişilmesi güç bir varlık olduğuna inandıkları sonucuna ulaşılmıştır. Sarı ve Sadık'ın (2011) ğretmen adayları ile yaptıkları çalışmada 51 öğretmen adayının demokrasinin daha çok kişisel çıkarlara hizmet eden, gücü elinde bulunduranların kendi istekleri doğrultusunda şekillendirdikleri bir yönetim biçimi olduğunu düşündükleri görülmüştür. Aynı çalışmada 36 öğretmen adayının da hayal, rüya, boş laf, vb. gibi metaforlarla demokrasinin imkansızlığına işaret ettikleri, toplumdaki demokrasi anlayışına eleştirel bir şekilde yaklaştıkları görülmüştür.

\section{Demokrasinin Unsurlarına Yönelik Algılar}

Araştırma sonuçlarl; demokrasinin unsurlarından ikisinin "hukuk" ve "adalet" olduğunu ortaya koymaktadır. Hukukun, temel hak ve özgürlükler temelinde, toplum ihtiyaçlarına göre belirlenmesi gerektiği düşünülmektedir. Korunması için; kişilerin hukuka saygı göstermesinin, hukukun devlet tarafindan garanti altına alınarak uymayanların cezalandirlmasinin gerekli olduğu belirtilmektedir. Adaletin, yasa ve hukuk yolu ile; eşitlik, düşünce hürriyeti, temel hak ve özgürlükler gibi demokrasinin unsurlart yolu ile; devlet kontrolü ile ve eğitim yolu ile tesis edilebileceği düşünülmektedir. Ancak bu görüşe zıt olarak araştırma kapsaminda, adaletin tesisinin mümkün olmadı̆̆ının da düşünüldüğü görülmektedir. Bu durum adalet sistemine güvenin yitirildiğini göstermektedir. Adaletin işlevi olarak; emniyet, güven, asayiş, özgürlük, bağımsızlık, devletin bekası ve haklı ile haksızın ortaya çıkması belirlenmiştir. Bu açıdan bakıldı̆̆ında adaletin doğru algllandı̆̆ı söylenebilir.

Sadık ve Sarı'nın (2012) ilköğretim öğrencilerinin demokrasi algılarını metaforlar aracılığıyla incelediği çalışmada da demokrasinin "adalet”, "eşitlik” ve "özgürlük” kavramlarıyla eş anlamlı bir yönetim biçimi olarak algılandığ 1 görülmüştür. Nicolescu-Waggonner (2016) hukukun; eşitlik ve adalet ilkeleri ile çok yakından bağlantılı olduğunu belirtmektedir. Arat (1985) adaletin tesisi, asayişin ve kamu düzeninin sağlanması için kanun hakimiyetinin şart olduğunu belirtmektedir. Hökelekli (2011) de adaletin; güçlü ile zayıfı, iyi ile kötüyü, mazlum ile zalimi ayırması bakımından oldukça önemli olduğunu, toplumda yaygın bir adalet anlayışı olmadığı zaman, güç odaklı ilişkilerin devreye girerek güçlünün güçsüzü ezdiği bir düzenin ortaya çıkacağını belirtmektedir.

Araştırma sonuçlarına göre; demokrasinin unsurlarından diğer ikisi "hürriyet" ve “merhamet"dir. Hürriyeti tanımlamak için; elzem, ön şart, özgürlük, temel hak ve özgürlük gibi 
kavramların kullanıldı̆̆ı belirlenmiştir. Katılımcılar, her insanın kendisine ve başkalarına zarar vermediği sürece hürriyete sahip olmasl gerektiğini vurgulamışlardır. Bu durum hürriyetin doğru algılandı̆̆ını göstermektedir. Kimlerin merhamet etmesi gerektiği ile ilgili farklı görüşler mevcuttur. Bazıları herkesin, bazıları iktidar sahipleri ve yöneticilerin, bazıları güçlüler, zenginler ve büyüklerin merhamet etmesi gerektiğini belirtmişlerdir. Hukuk devletinde merhamete ihtiyaç olmadığı, dolayısıla hiç kimsenin merhamet etmesi gerekmediği şeklinde bir görüş de mevcuttur. Kimlerin hürmet etmesi gerektiği ile ilgili olarak; bazıları herkesin, bazıları yöneticilerin, bazıları güçlülerin, bazılart ise küçükler ve fakirlerin hürmet etmesi gerektiğini belirtmişlerdir. Bu durum hürmetin yanlış algılandığını göstermektedir. Çünkü tüm insanların tüm insanlara karşı hürmet ve merhamet hisleri içinde olması insan olmanın bir gereğidir. Hangi konumda olursa olsun herkesin birbirine hürmet göstermesi gerekir.

Kartal, Öksüz, Öztürk ve Demir'in (2018) yaptıkları çalışmada öğretmen adaylarının, demokrasi kavramını eşitlik ve hürriyetle eş anlamlı olan özgürlük kavramlarıyla eş değer tuttukları görülmüştür. Aynı şekilde Karatekin ve Elvan'ın (2016) 8. sınıf öğrencilerinin demokrasi kavramına ilişkin bilişsel yapıları inceledikleri çalışmada da katılımcıların demokrasi kavramını en fazla ilişkilendirdiği ilk üç sözcük eşitlik, özgürlük ve hak olarak tespit edilmiştir. Gilbert (2005) merhameti, başkasının acısını giderme isteğini, acının kaynağını anlamayla ilgili bilişsel süreci ve merhametli eylemlerde bulunmakla ilgili davranışsal süreci içerisinde barındırdığını belirtmektedir. Bu konuda Mevlana çok güzel bir örnektir. Mevlana, bitki, hayvan ve insan alemini bir bütün halinde görür. $\mathrm{O}$, Müslüman olsun ya da olmasın bütün insanlara karş1 merhamet ve nezaket hisleri içinde olmanın gerekliliğine işaret eder (Kurt, 2007).

Araştırma sonuçlarına göre; demokrasinin unsurlarından diğer ikisi "muhalefet" ve "seçim” olarak belirlenmiştir. Muhalefetin mutlaka bulunması, söz sahibi olması ve hatta iktidarla aynı güce sahip olması gerektiği yönünde sonuçlara ulaşılmıştır. Muhalefetin sorumluluklarl olarak; doğruya doğru, yanlışa yanlış demek, farklı düşünceleri savunmak, tamamlayıcı olmak, yapıcı ve işbirlikçi olmak gibi görevler sayılmıştır. Muhalafete ilişkin olumlu algıların olması demokrasi açısında oldukça önemlidir. Seçimin olumlu özellikleri olarak; insanların özgürce kendilerini ifade edebilmeleri ve demokrasinin fiilen bir uygulaması olduğu ifade edilirken, olumsuz özellikleri olarak; her zaman doğru sonucu vermemesi, her zaman adil olmaması ve güven veren bir uygulama olmaması sayılmıştır. Nasıl olması gerektiği ile ilgili 
olarak ise; hakkaniyetli, tarafsız, usulüne uygun, özgür iradeyle ve herkesin katıllmı sağlanarak yapılması sayllmıştır. Güvenilir ve adaletli yapılan seçimlerin olumlu algılanması demokrasi açısından oldukça önemlidir.Güçlü, adaletli ve güvenilir muhalefet ve seçimler demokrasinin gelişimi için umut vadetmektedir.

Sadykova ve Tutar (2014) demokrasi ile muhalefet arasında pozitif bir ilişkinin var olduğunu ve muhalefetin demokratikleşmesinin önemli araçlarından biri olduğunu ifade etmektedirler. Başarılı bir seçim usulü oluşturan demokratik ülkelerde, özgür ve adil seçimler demokrasinin özünü oluşturur (Nicolescu-Waggonner, 2016). Ancak demokrasiyi yalnızca seçimlerle özdeşleştirmek doğru bir demokrasi algısı değildir. Bu doğrultuda Post (2005) demokrasi fikrinin oluşması için, seçim gibi belirli karar verme prosedürlerinin de gerçekten demokratik yollarla gerçekleşmesinin gerektiğini belirtirken, Aliefendioğlu (2005) da seçimlerin demokratik meşruiyet kazanması için, farklı görüşleri temsil eden partilerin serbestçe örgütlenebilmelerinin ve seçim kulvarında her türlü baskıdan uzak, özgürlükçü bir ortamda yarışabilmelerinin gerekli olduğunu belirtmektedir.

Araşttrma sonuçlarına göre; demokrasinin unsurlarından bir diğeri "çoğulculuk"tur. Katılımclların çoğulculuk kavramina genellikle olumlu anlamlar yüklediği görülmektedir. Olumlu algıların yanısıra bazı olumsuz algılar da mevcuttur. Bunlar; farklllıkların demokrasiyi zayıflatması ve ortak noktada birleşmeyi engellemesi görüşleridir. Bu durum demokrasi açısından olumsuz bir durumdur. Çünkü farkllliklar demokrasiyi zenginleştirmektedir ve demokratik bir hukuk ve adalet sistemi kurulduğunda ortak noktada birleşmek zor değildir. Öteki ile ilgili olumlu olarak; farklllık, güzellik, aynısı olmaktan iyi olan gibi sonuçlara ulaşılmıştır. Olumsuz olarak ise; topluma zararlı olan, bazen kötü olan ve olumsuz etkileri olan gibi bazı tanımlamalara ulaşılmıştır. Farkllıklarla ilgili olumlu olarak; farklılıkların olmasının doğal oluşu, tek tip insan oluşumunu engellemesi, zenginlik ve renk oluşu, toplumu gelişstirmesi, güçlendirirmesi ve dinamik tutması gibi özellikler saptanmıştır. Azınlıklarla ilgili olumsuz görüş̧ mevcut değildir. Azınlıklarla ilgili olumlu olarak ise; hak ve özgürlüklerini kullanabilmeli, fikirlerine değer verilmeli, kendi kimliklerini yaşamal, bask yapılmamal, parlamentoda temsil edilmeli, çoğunluk kadar değerli olmalı gibi yorumlar yapılmıştır. Bu durum demokrasinin gelişimi açısından azınlıkların olumlu algılandı̆̆ını göstermektedir.Demokrasi farklılık temeline dayanır ve çeşitlilik ve çoğulculuk olmadan demokrasi var olamaz. 
Bu araştırmanın sonucuna zıt olarak Kartal, Öksüz, Öztürk ve Demir'in (2018) Polonyalı ve Türk öğretmen adaylarının demokrasi algılarını karşılaştırmak için yaptıkları çalışmada, Polonyalı öğretmen adaylarının demokrasiye ilişkin “çoğulculuk” kavramını ön plana çıkardıkları, Türk öğretmen adaylarının ise "çoğunluk" kavramı üzerinde durdukları sonucuna ulaşılmıştır. Sarı ve Sadık’ın (2011) yaptıkları araştırmanın sonucunda öğretmen adaylarının demokrasiyle ilgili geliştirdikleri metaforların çoğunlukla eşitlik, bağımsızlık ve çokseslilik temaları altında toplandığı görülmüştür.

\section{Demokratik Toplum Özelliklerine Yönelik Algılar}

Araştırma sonunda demokratik toplum özellikleri ile ilgili olarak ilk ortaya çıkan unsur "devlet ve yönetici” özellikleridir. Demokratik toplumda devlet ve yöneticilerin hak ve özgürlükleri kısıtlamamasının ve güvence altına almasının, hürriyetin ve düşünce özgürlügünü sağlamasının, tüm düşüncelere saygı duymasının gerektiğinin düşünüldüğ̈̈ yönünde sonuçlara ulaşılmıştır. Hak, hukuk ve adalet konusunda; eşitlik ilkesinin korunması, adalet ve tarafsızlığın tesis edilmesi, hukuka bağlı kalınması, azınlıklar ve güçsüzlerin de haklarının korunarak haklı olanın yanında olunması gibi devlet ve yöneticilerin uygulaması gereken bazı ilkeler sonuç olarak belirlenmiştir. Bunlar demokratik devletlerin ve yöneticilerin temel görevleri arasında olduğundan devlet ve yöneticilerle ilgili doğru bir alglya sahip olunduğu söylenebilir. Demokratik toplumda bulunması gereken yönetici özellikleri ile ilgili olarak; empati yeteneğine sahip olma, liderlik yapabilme, ileri görüşlü olma, millete hizmetkar olma, bulunduğu konumun hakkını verme, halka örnek olma gibi özellikler sayılmıştır.

Aktan (2016) demokrasinin vazgeçilmez koşulunun siyasal özgürlükler olduğunu söylemekte ve demokrasiyi dar anlamda siyasal özgürlüklerin mevcut olduğu yönetim biçimi olarak tanımlamaktadır. Farabi, erdemli bir toplumda toplumsal adaletin önemine vurgu yapmakta ve adaleti kamusal mal ve hizmetlerin eşit bir şekilde dağıtılması ve mülkiyetin korunması üzerinden tanımlamaktadır (Akbal, 2015). Bilge de (2011) demokrasinin en önemli özelliklerinden birinin, bireyin toplum ve devlet adına feda edilmemesi, çoğunluğun tahakkümüne karşı, azınlığın hak ve özgürlüklerinin teminat altına alınması olduğunu belirtmektedir. Bagi (2009) yapılan araştırmaların demokrasinin toplumun refahı üzerinde olumlu gelişmeler sağladığını gösterdiğini, bu nedenle ülkelerin daha demokratik olmaya doğru ilerlemesi gerektiğini belirtmektedir. Aktan’a (2015) göre; “iyi yönetim” kavramının içerisinde 
diyalog ve uzlaşma yer almaktadır. Halk, önce hür iradesi ile mutabakata dayalı olarak temsilcilerini seçebilmeli (siyasal katılım ve temsil), onlara yönetme hakkını vermeli (temsili vekalet), yöneticiler ile yakın iletişim içinde bulunarak kamusal kararlara katılabilmeli (yönetime katılma) ve yöneticilerin güç ve yetkilerini kötüye kullanmalarını engellemek için onları kontrol (denetim) edebilmelidir.

Araştırma sonunda demokratik toplum özellikleri ile ilgili olarak ortaya çıkan diğer unsur "vatandaş" özellikleridir. Araştırmada vatandaşların sorumluluklart için bireysel ve toplumsal olarak iki ana başlık ortaya çıkmıştır. Toplumsal açıdan; toplumun gelişimine katkı sağlama, başkalarını önemseme, onlara yol gösterme ve onlarla bilgilerini paylaşma gibi topluma hizmetle ilgili sorumluluklarl; başkalarının hak ve özgürlüklerini klsıtlamama, onlar üzerinde baskl kurmama, onlara saygı duyma gibi insan hakları ile ilgili sorumlulukları; toplumsal barış için çalışma ve kutuplaşmak yerine birleşme gibi barışla ilgili sorumlulukları sayılmıştır. Vatandaşların bireysel sorumlulukları olarak ise; temel hak ve özgürlüklerine sahip çıkma, adalete riayet etme, hakların bilme ve kullanma gibi hak ve hukukla ilgili sorumluluklar; akll ve vicdan sahibi olma, özverili olma ve ahlaklı olma gibi ahlaki sorumluluklar, nitelikli yetişme ve potansiyelini keşfetme gibi eğitim ile ilgili sorumluluklar sayılmuştır. Vatandaş özelliklerinin demokratik bir bireyde olması gereken özellikler olduğu görülmektedir. Bu durum demokrasi açısından oldukça önemlidir.

Demokratik bir devletin bireylerinin din, ırk, sosyal sınıf, cinsiyet gibi değişik ve birbiriyle kesişen kimlik unsurları vardır ancak farklılıklara rağmen herkes tarafından eşit bir şekilde paylaşılan tek kimlik unsuru vatandaşlıktır (Bakioğlu \& Kurt, 2009). Westheimer ve Kahne (2004) demokrasinin gerek duyduğu vatandaş tiplerini; şahsi sorumluluğa sahip vatandaş, katılımcı vatandaş ve adalet merkezci vatandaş olarak saymıştır. Ersoy ve Öztürk (2015) de, iyi bir vatandaşın; farklı kültürleri kabul etmesi ve onlara saygı duyması, farklı kültürleri "biz" ve "onlar" bağlamından çıkaran kapsayıcı bir vatandaşlık algısına sahip olması gerektiğini belirtmektedir.

Araştırma sonuçları doğrultusunda aşağıdaki öneriler geliştirilmiştir:

Okul öncesinden başlayarak eğitimin her kademesindeki öğrencilerin demokrasi algılarının geliştirilmesi için öğrencilere; 
- özellikle temel haklar, farklılıklar, azınlıklar ve eşitlik gibi konularda doğru bilgilerin verildiği,

- uygulamalarda görülen aksaklıkların demokrasi kavramına mal edilmemesi gerektiği fikrinin kazandırıldığı bir demokrasi eğitimi verilmelidir.

Özellikle eğitim fakültelerindeki öğretmen adaylarının demokrasi algılarının gelişimi için Demokrasi ve İnsan Hakları dersi ön lisans, lisans ve lisans üstü düzeylerde seçmeli ders olarak öğretim programlarında yer almalıdır.

Demokrasi bilincine kavuşulabilmesi için;

- öğrencilere demokratik yöntemlerle, demokratik ve öğrenci merkezli ortamlarda eğitim verilmelidir.

- okullar demokratik bir kültüre kavuşturulmalı, kurumun tüm paydaşları karar alma süreçlerine dahil edilmelidir.

$\checkmark \mathrm{Bu}$ araştırmada yüksek lisans öğrencilerinin demokratik algıları incelenmiştir. Yapılacak araştırmalarda öğretmenlerin, velilerin, öğrencilerin demokratik tutum ve değer algıları birlikte araştırılmalıdır.

\section{Yazar Katkı Beyanı:}

1. Şeyma ŞAHIN: Veri toplama aracı geliştirme, veri toplama ve analizi, ön taslak yazımı, kavramsallaştırma, yöntem ve bulgular bölümlerinin düzenlenmesi

2. Burcu ÖKMEN: Veri toplama aracı geliştirme, veri toplama ve analizi, ön taslak yazımı, kavramsallaştırma, giriş ve sonuç bölümlerinin düzenlenmesi

3. Abdurrahman KILIÇ: Danışmanlık ve denetim, veri toplama, inceleme ve düzenleme

\section{Kaynakça}

Akbal, İ. (2015). Farabi siyasi düşüncesinde toplum, devlet yönetimi ve siyasal rejim sorunu. Türk İslam Siyasi Düşüncesi Kongresi, Aksaray.

Akseki, A. H. (2006). Ahlak ilmi ve İslam ahlakl. İstanbul: Yasin Yayınları.

Aktan, C. C. (2015). İdeal devlet ve iyi yönetim: Temel ilkeler, kurallar ve kurumlar. Hukuk ve İktisat Araştırmaları Dergisi, 7(1), 50-60. 
Aktan, C. C. (2016). İdeal bir siyasal yönetim arayişi ve anayasal demokrasi. Hukuk ve İktisat Araştırmaları Dergisi, 8(2), 1-20.

Aktaş, M. (2015). Demokrasi kavramına eleştirel bir bakış. Anemon Muş Alparslan Üniversitesi Sosyal Bilimler Dergisi, 3(1), 87-105.

Aliefendioğlu, Y. (2005). Temsili demokrasinin "seçim" ayağı. TBB Dergisi, 60, 71-96.

Anney, V. N. (2014). Ensuring the quality of the findings of qualitative research: looking at trustworthiness criteria. Journal of Emerging Trends in Educational Research and Policy Studies, 5(2), 272-281.

Arat, R. R. (1985). Yusuf Has Hacib. Kutadgu Bilig II. Ankara: AKDTYK Türk Tarih Kurumu Yayınları.

Ateş, H. (2017). İslam ve demokrasi üzerine. TESAM Akademi Dergisi, 215-224.

Bagi, S. K. (2009). Democracy and human well-being. Northeast Business \& Economics Association Proceedings, 29-32.

Bakioğlu, A., \& Kurt, T. (2009). Öğretmenlerin demokrasi vatandaşlık ve vatanseverlik algılarının nitel olarak incelenmesi. Marmara Üniversitesi Atatürk Eğitim Fakültesi Ĕ̈itim Bilimleri Dergisi, 29, 19-39.

Bal, M. S., \& Yiğittir, S. (2013). İlköğretim ve ortaöğretim öğrencilerinin demokrasi algılarının incelenmesi. Adlyaman Üniversitesi Sosyal Bilimler Enstitüsü Dergisi, 6(14), 195-220.

Berzeg, K. (1997). Liberal demokrasilerde insan algılaması ve uygulaması. Uluslararası Demokrasi, Hukuk ve İnsan Hakları Konferansı, Diyarbakır.

Bilge, M. (2011). Türkiye'de demokrasi kültürü: Siyaset ve toplum. TSA, 15(3), 49-60.

Bülbül, S. (1989). Demokrasi Eğitiminde Öneriler (Panel II). Demokrasi İçin Eğitim. Ankara: TED Yayinları.

Büyükkaragöz, S. (1989). Ortaöğretimde demokrasi eğitimi. Konya: Selçuk Üniversitesi Eğitim Fakültesi.

Catterall, M., \& Ibbotson, P. (2000). Using projective techniques in education research. British Educational Research Journal, 26(2), 245-256.

Conn, P. H. (1973). Social pluralism and democracy. American Journal of Political Science, $17(2), 237-254$.

Cresswell, J. W. (2014). Research design: Qualitative, quantitative and mixed methods approach. USA: Sage Publication.

Çal, S. (2010). Demokrasi ve hukuk üzerine. Ankara: Ankara Üniversitesi Hukuk Fakültesi Yayınları.

Dahl, R. A. (2001). Demokrasi üstüne (Çev. B. Kadıŏlu). Ankara: Phoenix Yayınevi.

Dewey, J. (2001). Democracy and education. USA: The Pennsylvania State University.

Duman, B. (2008). Öğrenme-öğretme sürecindeki entelektüel şizofrenizm. Türk Eğitim Bilimleri Dergisi, 6(2), 287-321. 
Engin, Z. Ö. Ü. (2014). Birey kavramının gelişimi ve insan hakları. İstanbul Üniversitesi Hukuk Fakültesi Mecmuast, 72(1), 201-218.

Ersoy, A. F., \& Öztürk, F. (2015). Bir vatandaşlik değeri olarak yurtseverlik: Sosyal Bilgiler öğretmen adaylarının algısı. Ilkögretim Online, 14(3), 974-992.

Fraenkel, J. R., \& Wallen, N. (2000). How to design and evaluate research in education (4th ed.). NY: McGraw-Hill.

Gilbert, P. (2005). Compassion and cruelty: A biopsychosocial approach. In (Ed. P. Gilbert), Compassion: Conceptualisations, research and use in psychotherapy (pp. 9-74). England: Routledge.

Golafshani, N. (2003). Understanding reliability and validity in qualitative research. The Qualitative Report, 8(4), 597-606.

Gülmez, M. (2009). İnsan hakları olarak sosyal haklar ve sosyal haksızlıklar. Akdeniz Üniversitesi Uluslararası Sosyal Haklar Sempozyumu, Antalya.

Hökelekli, H.(2011). Ailede, okulda, toplumda dĕ̆erler psikolojisi ve eğitimi. İstanbul: Timaş Yayınları.

Karatekin, K., \& Elvan, Ö. (2016). 8. sınıf öğrencilerinin demokrasi kavramına ilişkin bilişsel yapıları. Abant İzzet Baysal Üniversitesi Eğitim Fakültesi Dergisi, 16, 1405-1431.

Kartal, A., Öksüz, Y., Öztürk, M. B., \& Demir, E. G. (2018). Sınıf öğretmeni adaylarının demokrasi algısı: Polonya-Türkiye karşılaştırması. İlköğretim Online, 17(2), 562-579.

Khare, N. (2017). Separation of power and rule of law in india, unswerving deepening of democracy. International Journal of Recent Research Aspects, 4(8), 114-117.

Koyuncu, A. A. (2015). Dört farklı perspektiften İslam demokrasi tartışmaları. İnsan ve Toplum Bilimleri Araştırmaları Dergisi, 4(3), 705-727.

Kurt, H. (2007). Mevlana'da insanliğin birliği ve diyalog. Harran Üniversitesi İlahiyat Fakültesi Dergisi, 18, 167-176.

Kvale, S. (2006). Dominance through interviews and dialogues. Qualitative Inquiry, 12(3), 480500 .

Lai, B., \& Melkonian-Hoover, R. (2005). Democratic progress and regress: The effect of parties on the transitions of states to and away from democracy. Political Research Quarterly, 58(4), 551-564.

Lincoln, Y. S., \& Guba, E. G. (1985). Naturalistic inquiry. Newbury Park, CA: Sage Publications.

Locke, J. (2004). Hükümet üzerine ikinci inceleme (Çev. Fahri Bakırcı). Ankara: Liberte Yayınları.

Nicolescu-Waggonner, C. (2016). No rule of law, no democracy: Conflicts of interest, corruption, and elections as democratic deficits. USA: State University of New York Press. 
Nielsen, K. (1979). Radical egalitarian justice: Justice as equality. Social Theory and Practice, 5(2), 209-226.

Novak, J. M. (1994). Democratic teacher education: Programs, processes, problems, and prospects. Albany: State University of New York Pres.

Olatunji, F. O. (2013). Democracy and the challenge of the rules of law in developing democratic society. Beytulhikme An International Journal of Philosophy, 3(2), 67-79.

Osler, A., \& Starkey, H. (1994). Fundamental issues in teacher education for human rights: A European perspective. Journal of Moral Education, 23, 349-360.

Özdaş, F., Ekinci, A., \& Bindak, R. (2014). Analyzing teachers' attitudes towards democracy in terms of some variables. İnönü Üniversitesi Eğitim Fakültesi Dergisi, 15(3), 65-81.

Özdemir, G. (2013). Farklılıkların kesiştiği coğrafyalar için bir öneri: Radikal demokrasi. Yönetim ve Ekonomi, 20(1), 73-93.

Palombella, G., \& Morlino, L. (2010). Rule of law and democracy: Inquiries into internal and external issues. Leiden: Brill NV.

Post, R. (2005). Commentaries: "thinking about democracy" democracy and equality. Law, Culture and the Humanities, 1, 142-153.

Reidy, D. A. (2001). Pluralism, liberal democracy, and compulsory education: Accommodation and assimilation. Journal of Social Philosophy, 32(4), 585-609.

Ritchie, J., Lewis, J., \& Elam, G. (2003). Designing and selecting sample. In Qualitative Research Practice: A Guide For Social Science Students and Researchers (Ed. Jane Ritchie \& Jane Lewis), 77-108, London: Sage.

Rosenfeld, M. (2014). Hukukun üstünlüğü ve anayasal demokrasinin meşruiyeti (Çev. V. Aslan). Hukuk Kuramı, 1(2), 30-61.

Sadık, F., \& Sarı, M. (2012). Çocuk ve demokrasi: İlköğretim öğrencilerinin demokrasi algılarının metaforlar aracılığıyla incelenmesi. Uluslararası Cumhuriyet Eğitim Dergisi, $1(1), 48-62$.

Sadykova, G., \& Tutar, H. (2014). Örgütsel demokrasi ve örgütsel muhalefet arasındaki ilişki üzerine bir inceleme. İsletme Bilimi Dergisi, 2(1), 1-16.

Sarı, M., \& Sadık, F. (2011). Öğretmen adaylarının demokrasi algıları (Çukurova Üniversitesi örneği). Uluslararası Eğitim Programları ve Öğretim Çalışmaları Dergisi, 1(2), 67-82.

Sartori, G. (2011). Demokrasi teorisine geri dönüş (Çev. T. Karamustafaoğlu \& M. Turhan). Liberal Düşünce, 16(61-62), 39-48.

Schmidh, M. (2002). Demokrasi kuramına giriş (Çev. M. E. Köktaş). Ankara: Vadi Yayınları.

Tosun, C. M. (2015). John Rawsl'un sosyal hakların taşıyıcısı ve demokratik toplumun temeli olan "etik kişi”"si. VII. Sosyal İnsan Hakları Uluslararası Sempozyumu, Denizli.

Tunç, H. (2008). Demokrasi türleri ve müzakereci demokrasi kavramı. Gazi Üniversitesi Hukuk Fakültesi Dergisi, 12(1-2), 1113-1132.

Turner, B. (1986). Equality. USA: Tavistock Publication. 
Vander Hook, S. (2011). Democracy. USA: Abdo Consulting Group, Inc.

Westheimer, J., \& Kahne, J. (2004). What kind of citizen? The politics of educating for democracy. American Educational Research Journal, 41(2), 237-269.

Yargıc1, A. (2007). Kur'an'a göre şura ve demokrasi. Dini Araştırmalar, 9(27), 171-183.

Yüce, S. G., \& Demir, Ö. (2011). Polis adaylarının “demokrasi” kavramına ilişkin algılarının metaforlar aracılığıla incelenmesi. Polis Bilimleri Dergisi, 13(2), 147-178. 